\title{
Sub-cellular localization of Tetrodotoxin in the Tissues of the Pufferfish Takifugu Oblongus
}

\author{
Indumathi S M and Samanta Sekhar Khora* \\ Department of Integrative Biology, School of Biosciences and Technology, VIT University, Vellore - 632014, Tamil Nadu, INDIA.
}

\begin{abstract}
Objective: The prime objective of this study is to determine the origin of Tetrodotoxin in the pufferfish Takifugu oblongus. Methods: Ultracentrifugation was performed to separate the tissues into various cellular fractions. Mouse bioassay was done to analyse the toxicity of different fractions from skin, liver and ovary of $T$. oblongus. The toxic fractions were subjected to HPLC-UV detection, to detect the presence of tetrodotoxin and quantify it. Results: Cytosolic fractions of skin, liver and ovary were extremely toxic and the presence of tetrodotoxin was proved on comparison with the retention time of standard toxin. Conclusions: These results suggest that the origin of tetrodotoxin could be endogenous or biosynthesized by the pufferfishes themselves. Clarifying the contradictions about the origins of TTX in puffers would allow researchers to accurately identify its role and toxicogenesis of the organisms which possess tetrodotoxin.
\end{abstract}

Key words: Takifugu oblongus, Tetrodotoxin, Ultracentrifugation, Mouse Bioassay, HPLC.

\section{INTRODUCTION}

Tetrodotoxin (TTX) is a potent neurotoxin which selectively blocks the voltage gated sodium channels in nerve cell membranes, thereby becoming fatal to humans. It was earlier believed to be present only in pufferfishes but was later found that TTX is also found in various other marine and terrestrial organisms. Though TTX has been studied widely, its origin and physiological role in pufferfish is not clearly established yet. Few reports have proposed the concept of exogenous origin of TTX, i.e., it was presumed that microorganisms, especially bacteria in the marine environment produce tetrodotoxin and this toxin enters the puffers through their algal food source. ${ }^{1-9}$ While some researchers have suggested that the origin of TTX to be endogenous and it is biosynthesized. The intracellular distribution of TTX in different pufferfish species were performed earlier. ${ }^{14-16}$ Various methods were employed in locating TTX at the intracellular levels and they are HPLC, LCFABMS, and monoclonal antibody based immunoenzymatic and immunohistological methods.

Takifugu oblongus is a species of pufferfish which is available along the Indian coasts. Even though little studies on T. oblongus have been performed by researchers worldwide, reports from India are completely lacking. The toxicity of T. oblongus and presence of Tetrodotoxin in it has been studied previously. The present study is the first report from India that is targeted to find the subcellular distribution or molecular origin of TTX in the tissues of T. oblongus by mouse bioassay and HPLC-UV detection, which is contradictory to the concept of microbial origin of TTX. It is an attempt to determine the toxigenesis of the pufferfish T. oblongus, the origin of TTX and to explain the physiological functions of TTX in pufferfish.
Submission Date: 29-11-2016; Revision Date: 06-01-2017; Accepted Date: 15-02-2017

DOI: 10.5530/ijper.51.3.68 Correspondence:

Dr. Samanta Sekhar Khora, Sr. Professor,

Department of Integrative Biology, School of Biosciences and Technology VIT University, Vellore 632014, Tamil Nadu, INDIA E-mail: sskhora@vit.ac.in

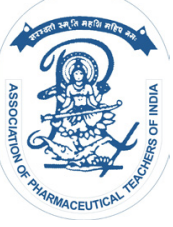

www.ijper.org 


\section{MATERIALS AND METHODS}

\section{Specimen Collection}

Specimens of Takifugu oblongus (Figure 1) were collected from Kasimedu fishing harbour, Chennai, Tamil Nadu. The specimens were tightly packed, transferred in Icebox to the Medical Biotechnology Lab, VIT University and they were maintained in a deep freezer at $-20^{\circ} \mathrm{C}$ until use. ${ }^{17,18}$

\section{Experimental Animals}

Male Swiss albino mice weighing between 18-22 g were issued by and maintained in the Animal House, VIT University for experimentation. ${ }^{19,20}$ The study had strictly followed the guidelines of Committee for the Purpose of Control and Supervision on Experiments on Animals (CPCSEA). The experimental procedures followed, were approved by the Institutional Animal Ethical Committee (IAEC), VIT University (Registration No: 197/BC/06/CPCSEA). Chloroform was used as an anaesthetic agent for control mice before dissections and handling of mice was done ethically to reduce pain and suffering.

\section{Ultracentrifugation}

The specimens were dissected and the organs particularly Skin, Liver and Ovary were removed. $5 \mathrm{~g}$ of each tissue is homogenized with 3 volumes of ice-cold $20 \mathrm{mM}$ MOPS-KOH buffer ( $\mathrm{pH}$ 7.2), containing 60 $\mathrm{mM} \mathrm{KCl}, 180 \mathrm{mM}$ sucrose, $1 \mathrm{mM}$ EGTA and $10 \mathrm{mM}$ phenylmethanesulfonyl fluoride (PMSF) and filtered. The filtrate was successively centrifuged at $100 \mathrm{~g}$ for 20 $\mathrm{min}$, at $800 \mathrm{~g}$ for $2 \mathrm{~min}$, at $12,000 \mathrm{~g}$ for $20 \mathrm{~min}$ and at $100,000 \mathrm{~g}$ for $60 \mathrm{~min}$ to fractionate into "blood cell fraction", "nuclear fraction", "mitochondrial fraction" and "microsomal fraction". The supernatant finally obtained was referred to "cytosol fraction". ${ }^{21}$

\section{Toxin extraction}

Except the cytosol fraction, other fractions were washed twice with the MOPS-KOH buffer to avoid the contamination with the cytosol fraction and resuspended in $1 \mathrm{ml}$ of the same buffer. Toxins were extracted from each fraction by heating with $0.1 \%$ acetic acid in boiling water bath for $10 \mathrm{~min}$ at $60^{\circ} \mathrm{C}$. The extracts were cooled, filtered and stored for further studies. ${ }^{14}$

\section{Mouse Bioassay}

Even though toxicity analysis is performed through Brine shrimp lethality and cytotoxicity assays in most laboratory practices, ${ }^{22,23}$ Mouse bioassay is the gold standard for basic toxicity assessments. ${ }^{19}$ The mice were separated into 6 groups, with each group having
3 mice. First group is maintained as control group and it receives $1 \mathrm{ml}$ of $0.1 \%$ acetic acid. One $\mathrm{ml}$ of extract from all the cellular fractions (undiluted) were injected into groups of mice split accordingly. The injected mice were observed for toxicity symptoms and death for few minutes. If the mice die before 4 minutes, the extracts were diluted with $5 \mathrm{mg} / \mathrm{ml}$ Phosphate buffered saline (PBS). The toxicity of the extracts in Mouse Units (MU g-1) were calculated by the dose-death time relationship, where $1 \mathrm{MU}$ is defined as the amount of pure toxin (approximately $0.22 \mu \mathrm{g}$ ) required to kill a $20 \mathrm{~g}$ male mouse within 30 min of injection.

\section{High Performance Liquid Chromatography (HPLC) Conditions}

The samples were detected for presence of TTX on Shimadzu SPD-20A Prominence with UV-Vis Detector and a reverse phase column (Hypersil ${ }^{\mathrm{TM}}$ BDS C18 column, $250 \times 4 \mathrm{~mm}, 5 \mu \mathrm{m}){ }^{24-26} 0.04 \%$ of phosphoric acid was used as mobile phase with a flow rate of $1 \mathrm{ml} /$ min at $30^{\circ} \mathrm{C}$, and the UV wavelength set was $195 \mathrm{~nm} .{ }^{24}$

\section{RESULTS}

\section{Mouse Bioassay}

As a result of mouse bioassay, the toxicity of the cellular fractions of the pufferfish Takifugu oblongus was determined. Cytosolic fraction showed maximum toxicity followed by death of mice within 5 minutes, while other fractions showed least toxicities followed by death after $35 \mathrm{~min}$. Hence the other fractions could not be considered for calculation of toxicity in mouse units (MU) and presence of TTX. Cytosol fraction from ovary samples showed maximum toxicity with $228.31 \mathrm{MU} / \mathrm{g}$, followed

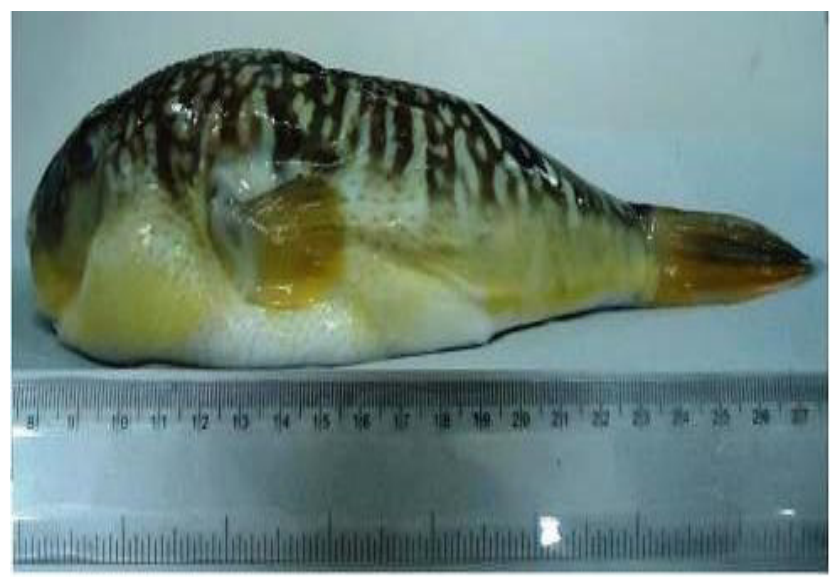

Figure 1: A specimen of Takifugu oblongus from Kasimedu Har- 

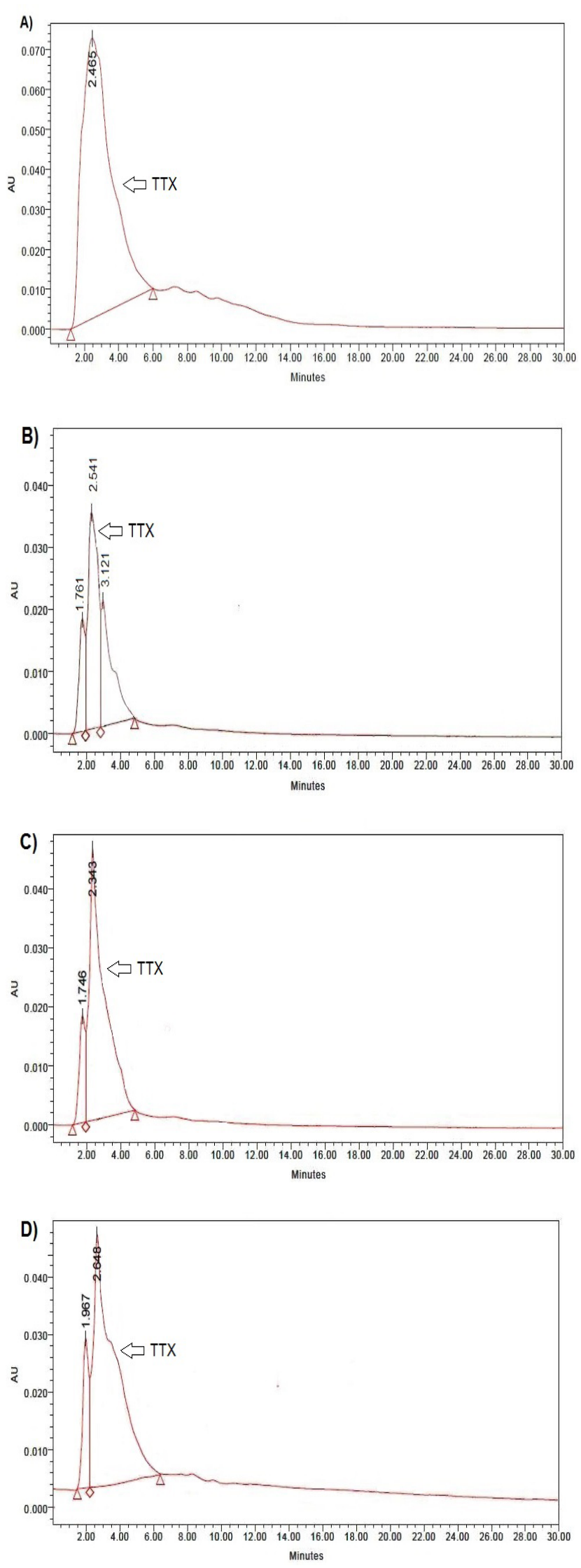

Figure 2: HPLC Chromatograms showing peaks for TTX at similar retention times for A) Standard TTX B) Skin fraction C) Liver fraction D) Ovary fraction. by the liver cytosolic fraction with $184.5 \mathrm{MU} / \mathrm{g}$ and skin with $83.43 \mathrm{MU} / \mathrm{g}$ (Table 1). The approximate amount of TTX and the degree of toxicity were also expressed with the calculated mouse units (MU).

\section{HPLC}

Standard TTX $(0.1 \mathrm{mg} / \mathrm{ml})$ showed a characteristic peak at the retention time of 2.465 (Figure 2A). The 3 cytosolic fractions showed characteristic peaks for TTX at closer retention times viz, 2.541 for skin sample, 2.343 for liver sample and 2.648 for ovary sample (Figures 2B, C \& D). The calibration curve was plotted with the standard and analyte concentration in the test samples was estimated. Ovarian cytosolic fraction contained about $45 \mu \mathrm{g}$, liver sample with $37 \mu \mathrm{g}$ and skin sample with 14 $\mu \mathrm{g}$ of TTX (Table 1).

\section{DISCUSSION}

The origin of Tetrodotoxin has always been a controversy amidst researchers worldwide. Since many years, it has been believed that pufferfishes acquire TTX and its congeners through its food chain. ${ }^{27,28}$ But this hypothesis is yet to be confirmed. The present study aims at understanding the distribution of TTX in the tissues of the pufferfish Takifugu oblongus. Mouse bioassay revealed that the cytosolic fractions of all the tissues exhibited extreme toxicities, while rest of the fractions exhibited least toxicities. It could be suggested that the other fractions should be containing traces of TTX, so that it produced toxicity symptoms very lately leading to slow death.

The cytosolic fractions of skin, liver and ovary of the puffer T. oblongus were subjected to HPLC separations through which the presence of TTX was detected and quantified. The Limit of Quantification (LOQ) of the toxin in the present study is $0.1 \mathrm{mg}$ and Limit of Detection (LOD) is $0.01 \mathrm{mg}$. The approximate amount of toxin quantified from mouse bioassay and HPLC are closer proving the reliability of the work. Few miscellaneous peaks were also found along with T'TX in HPLC as the samples were not purified. But when compared to the conventional mouse bioassay, instrumental analyses

\section{Table 1: Amount of TTX quantified through Mouse} Bioassay and HPLC

\begin{tabular}{|c|c|c|}
\hline Samples & Mouse Bioassay* $^{*}$ & HPLC* \\
\hline Skin & $18.35 \mu \mathrm{g}$ & $14 \mu \mathrm{g}$ \\
\hline Liver & $40.59 \mu \mathrm{g}$ & $37 \mu \mathrm{g}$ \\
\hline Ovary & $50.16 \mu \mathrm{g}$ & $45 \mu \mathrm{g}$ \\
\hline
\end{tabular}


give more precise and accurate detection levels of TTX and are more sensitive.

This work is just another attempt which forms the base in clarifying the ambiguities regarding the origin of TTX. It suggests the endogenous origin of the toxin, because it is impossible for a hydrophilic compound like TTX to permeate the animal cell membranes that are made up of bilayered lipids which is strongly hydrophobic. More studies are required to identify if the toxin is bound or unbound to proteins or RNA inside the organelles ${ }^{29,30}$ which would suggest the unknown role of TTX inside the cells. Once the role of TTX is understood, the toxification of pufferfishes could also be predicted thereby forming a substantial theory regarding the origin of TTX.

\section{CONCLUSION}

Pufferfishes, in general, are a great disaster to some maritime Asian countries. The ability of pufferfish to puff several times of its body size is its major defence mechanism. Yet it harbours the potent neurotoxin tetrodotoxin in its body. Identifying the origin of TTX is highly inevitable which would pave way in basic understanding of its role in pufferfish.

\section{ACKNOWLEDGEMENT}

The authors are grateful to the authorities of VIT University, Vellore, Tamil Nadu, India, for providing the required facilities, their constant encouragement and support.

\section{CONFLICTS OF INTEREST}

The authors hereby declare that we have no conflict of interest

\section{ABBREVIATIONS}

TTX: Tetrodotoxin; HPLC-UV: High Performance Liquid Chromatography-Ultra Violet; LC-FABMS: Liquid Chromatography-fast atom bombardment mass spectrometry; CPCSEA: Committee for the Purpose of Control and Supervision on Experiments on Animals; IAEC: Institutional Animal Ethical Committee; MOPS$\mathrm{KOH}$ : (3-(N-morpholino)propanesulfonic acid)-Potassium hydroxide; $\mathrm{KCl}$ : Potassium Chloride; EGTA: Ethylene glycol-bis( $\beta$-aminoethyl ether)-N,N,N',N'-tetraacetic acid); PMSF: Phenylmethanesulfonyl fluoride; PBS: Phosphate buffered saline; MU: Mouse Bioassay; LOQ: Limit of Quantification; LOD: Limit of Detection.

\section{REFERENCES}

1. Gallacher S, Birkberk TH. Effect of phosphate concentration on production of tetrodotoxin by Alteromonas tetraodonis. Appl Environ Microbiol. 1993;59(11):3981-3.

2. Hwang DF, Cheng CA, Chen HC, Jeng SS, Noguchi T, Ohwada K, et al. Microflora and tetrodotoxin producing bacteria in the lined moon shell Natica lineata. Fish Sci. 1994;60(5):567-71.

3. Matsui T, Taketsugu S, Kodama K, Ishii A, Yamamori K, Shimizu C Studies on the toxification of puffer fish. Production of tetrodotoxin by the intestinal bacteria of a puffer fish, Takifugu niphobles. Nippon Suisan Gakk. 1989;55:2199-203.

4. Narita H, Matsubara S, Miwa N, Akahane, S, Murakami M, Goto T, et al. Vibrio alginolyticus, a TTX-producing bacterium isolated from the starfish Astropecten polyacanthus. Nippon Suisan Gakk. 1987;53:617-21.

5. Noguchi T, Jeon JK, Arakawa O, Sugita H, Deguchi $Y$, Shida $Y$, et al. Occurrence of tetrodotoxin and anhydrotetrodotoxin in Vibrio sp. isolated from the intestines of a xanthid crab, Atergatis floridas. J Biochem. 1986;99(1):311.

6. Simidu U, Noguchi T, Hwang DF, Shida Y, Hashimoto K. Marine bacteria which produce tetrodotoxin. Appl Environ Microbiol. 1987;53:1714-5.

7. Yasumoto T, Yasumura D, Yotsu M, Michishita T, Endo A, Kotaki Y. Bacterial production of tetrodotoxin and anhydrotetrodotoxin. Agri Biol Chem. 1986;50(3):793-5.

8. Yotsu M, Yamazaki T, Meguro Y, Endo A, Murata M, Naoki H, et al. Production of tetrodotoxin and its derivatives by Pseudomonas sp. isolated from the skin of pufferfish. Toxicon. 1987;25:225-8.

9. Jal S, Khora SS. An overview on the origin and production of tetrodotoxin, a potent neurotoxin. J Appl Microbiol. 2015;119(4):907-16.

10. Hanifin CT, Brodie ED III, Brodie ED Jr. Tetrodotoxin levels of the roughskin newt, Taricha granulosa, increase in long-term captivity. Toxicon. 2002;40(8):1149-53.

11. Kim YH, Brown GB, Mosher HS, Fuhrman FA. Tetrodotoxin: occurrence in atelopid frogs of Costa Rica. Science. 1975;189(4197):151-2.

12. Kotaki Y, Shimizu Y. 1-Hydroxy-5, 11-dideoxytetrodotoxin, the first N-hydroxy and ring-deoxy derivative of tetrodotoxin found in the newt Taricha granulosa. J Am Chem Soc. 1993;115(3):827-30.

13. Matsumura K. Production of tetrodotoxin in puffer fish embryos. Environ Toxicol Pharm. 1998;6(4):217-9.

14. Nagashima $Y$, Hamada $Y$, Ushio H, Nishio S, Shimakura K, Shiomi K. Subcellular distribution of tetrodotoxin in puffer fish liver. Toxicon. 1999;37(12):1833-7.

15. Mahmud Y, Arakawa O, Ichinose A, Tanu MB, Takatani T, Tsuruda K, et al. Intracellular visualization of tetrodotoxin (TTX) in the skin of a puffer Tetraodon nigroviridis by immunoenzymatic technique. Toxicon. 2003;41(5):605-11

16. Tanu MB, Mahmud Y, Takatani T, Kawatsu K, Hamano Y, Arakawa O, et al. Localization of tetrodotoxin in the skin of a brackishwater puffer Tetraodon steindachneri on the basis of immunohistological study. Toxicon. 2002;40(1):103-6.

17. Ghosh S, Hazra AK, Banerjee S, Mukherjee B. The seasonal toxicological profile of four puffer fish species collected along Bengal coast India. Indian J Mar Sci. 2004;33(3):276-80.

18. Mandal N, Jal S, Mohanapriya K, Khora SS. Assessment of toxicity in puffer fish (Lagocephalus lunaris) from South Indian coast. Afr J Pharm Pharmacol. 2013;7(30):2146-56.

19. Yu CF. A comprehensive study of the Hong Kong puffer fishes and their toxins, Ph. D. Dissertation, Hong Kong: Hong Kong Polytechnic University; 2003.

20. Mondal S, Ghosh D , Sagar N , Ganapaty S. Evaluation of Antioxidant, Toxicological and wound healing Properties of Hibiscus rosa-sinensisL. (Malvaceae) ethanolic leaves extract on different Experimental animal models. Ind J Pharm Edu Res. 2016;50(4):620-37.

21. Carroll M. Organelles. London: Macmillan Education Ltd; 1989.

22. Kalt FR, Cock IE. Gas chromatography-mass spectroscopy analysis of bioactive petalostigma extracts: Toxicity, antibacterial and antiviral activities. Pharmacognosy Res. 2014;10(37):37-49. 
23. Bangale GS, Kesarala R, Shinde GV. Enhanced Tumor Targeting and Antitumor Activity of Gemcitabine Encapsulated Stealth Liposome's. Ind J Pharm Edu Res. 2015;49(4):304-19.

24. Qun $\mathrm{Y}, \mathrm{Fu} \mathrm{Yu} \mathrm{PH}$, Zhong $\mathrm{Li} \mathrm{H}$. Detection of tetrodotoxin and bacterial production by Serratia marcescens. World J Microbiol Biotechnol. 2005;21(6):1255-8.

25. Puranik M, Wadherb S, Sharmaa K. A Simple, Novel Validated Stability Indicating RP-HPLC method for estimation of Duloxetine $\mathrm{HCl}$ in Capsule Pharmaceutical Formulation. Ind J Pharm Edu Res. 2014;48(3):91-8.

26. Pappula N, Chintala P. Development and Validation of RP-HPLC Method for the Simultaneous Estimation of Paracetamol and Flupirtine Maleate in Pharmaceutical Dosage Form. Ind J Phar Edu Res. 2014;48(Suppl);34-9.
27. Matsui T, Hamada S, Konosu S. Difference in accumulation of puffer fish toxin and crystal-line tetrodotoxin in the puffer fish, Fugu rubripes rubripes. Nippon Suisan Gakk. 1981;47:535-7.

28. Saito T, Maruyama J, Kanoh S, Jeong JK, Noguchi T, Harada T, et al. Toxicity of the cultured puffer fish Fugu rubripes rubripes along with their resistibility against tetrodotoxin. Nippon Suisan Gakk. 1984;50:1573-75.

29. Nagashima Y, Nagai T, Shiomi K, Tanaka M, Taguchi T. Tetrodotoxin associated high molecular weight substances from toxic pufferfish liver. Nippon Suisan Gakk. 1993;59:1177-82.

30. Kodama M, Noguchi T, Maruyama J, Ogata T, Hashimoto K. Release of tetrodotoxin and paralytic shellfish poison from puffer liver by RNase. J Biochem. 1983;93(1):243-7.

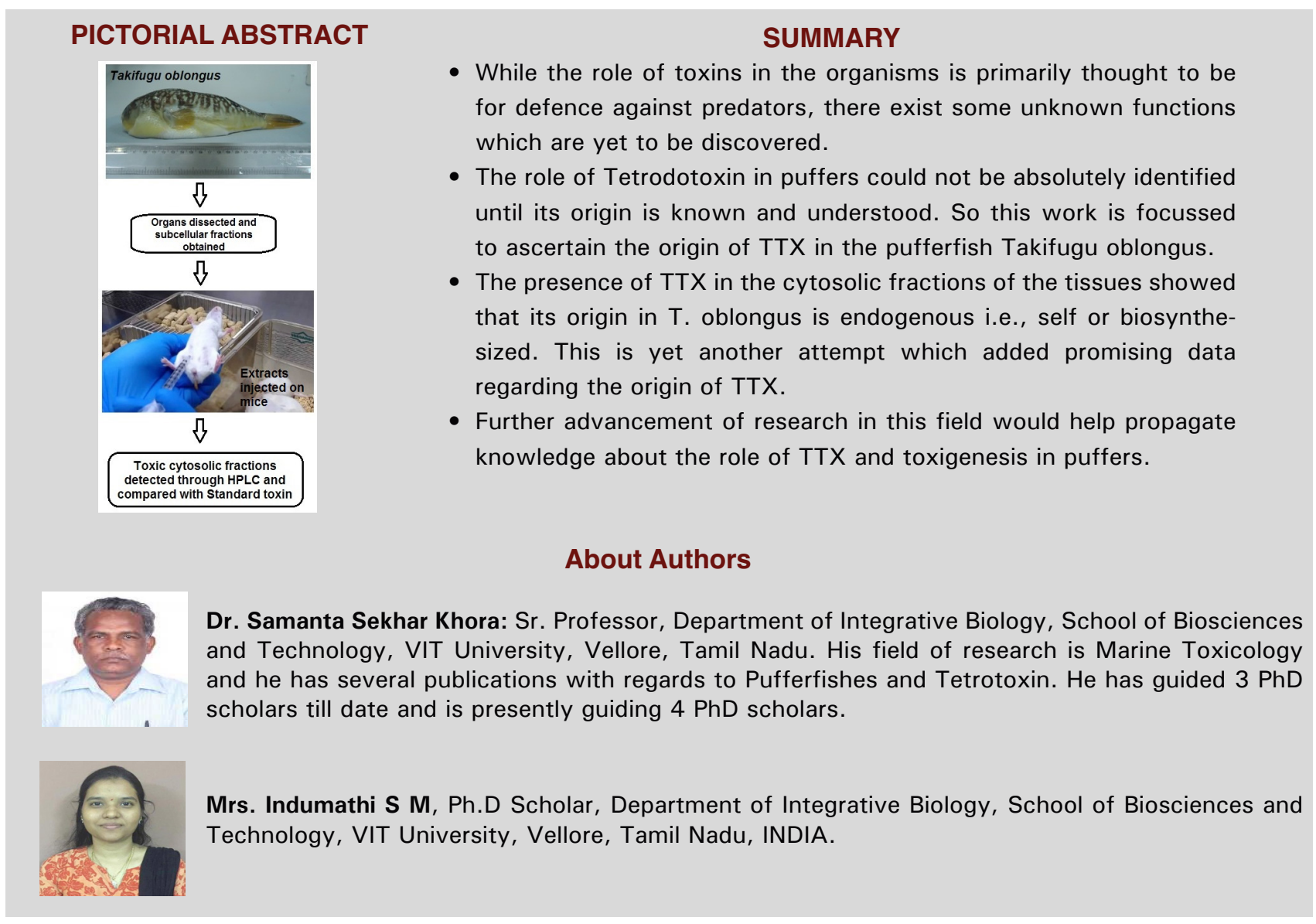

Cite this article: Indumathi SM, Khora SS. Sub-cellular localization of Tetrodotoxin in the tissues of the pufferfish Takifugu oblongus. Indian J of Pharmaceutical Education and Research. 2017;51(3):407-11. 